\title{
Simulation of the Occurrence of Water Runoff in Soils Under Cultivation of Industrial Tomato Irrigated by Center Pivot
}

\author{
Diogo. H. M. Moraes ${ }^{1}$, José Alves Júnior ${ }^{1}$, Marcio Mesquita ${ }^{1}$, Adão. W. P. Evangelista ${ }^{1}$, Derblai Casaroli ${ }^{1}$ \\ \& Rafael Batistti ${ }^{1}$ \\ ${ }^{1}$ College of Agronomy, Federal University of Goiás, Goiânia, Brazil \\ Correspondence: Diogo H. M. Moraes, College of Agronomy, Federal University of Goiás, Goiânia, Brazil. Tel: \\ 55-649-9243-3948. E-mail: diogo.slmb@gmail.com
}

$\begin{array}{ll}\text { Received: February 19, } 2019 & \text { Accepted: March 24, } 2019 \quad \text { Online Published: May 31, } 2019 \\ \text { doi:10.5539/jas.v11n7p48 } & \text { URL: https://doi.org/10.5539/jas.v11n7p48 }\end{array}$

The research is financed by Foundation for Research Support of State of Goiás (FAPEG).

\begin{abstract}
The tomato crop is almost totally irrigated. Among the irrigation methods utilized, mechanized sprinkling by center pivot stands out in tomato cultivation. A cultural treatment used in the tomato is the synchronization of the irrigations with the applications of the pesticides since with the leaf wetting the plants become unprotected and susceptible to diseases. In an attempt to reduce pesticide applications, growers seek to increase the time between irrigations, however, there are limitations, inherent to the soil and the irrigation system itself. The objective of this work was to simulate the soil water runoff tendency for irrigation management in the tomato crop, simulating three different types of soils (sandy, medium and clayey), three declines ( 0,5 and 10\%), and two types of deflectors (I-Wob and Spray). For this, four pivot sizes $(25,50,75$ and $100 \mathrm{ha})$ were defined and the methodology of maximum allowable precipitation estimated by the Newton-Raphson numerical technique was used to verify the different runoff conditions. The results showed that clayey soils are more susceptible when compared to medium and sandy soils, to surface runoff. Pivots of 100, 75 and 50 ha present greater susceptibility to runoff, with 25 ha being the best suitability for infiltration capacity in both soils. There is a percentage reduction of the maximum allowable rainfall of $40.74 \%( \pm 1.54)$ when the terrain is plan and pass to have $5 \%$ inclination and $22.99 \%( \pm 1.47)$ between 5 and $10 \%$. I-Wob type deflectors have a better distribution of application, a consequently better relation with the maximum allowable precipitation intensity and less possibility of the surface runoff.
\end{abstract}

Keywords: Solanum lycopersycum, infiltration, application intensity, sprinkling

\section{Introduction}

The tomato crop (Solanum lycopersycum) for industrial processing has great socioeconomic importance in state of Goiás, Brazil, being responsible for $65 \%$ of the production of this crop in the country (FAEG, 2014). The tomato for processing is almost totally irrigated and the sprinkler irrigation method is the most used in this crop, with the predominance of the center pivot system which is used in more than $90 \%$ of the areas (Marouelli, W. Silva, H. Silva, \& Braga, 2012).

The center pivot is characterized by the increasing flow rate of the sprinklers from the base to the final end, keeping the irrigation levels constant along the lateral line, being this variable a function of the speed of movement of the equipment (Silva \& Azevedo, 1998). Thus, the water application rate increases as a function of sprinkler flow rate, lateral displacement velocity and wetted diameter by the emitters, i.e., the greater the area irrigated by the equipment, the greater the probability of surface runoff. This excessive application of water by the equipment is destructive and causes soil saturation, leaching the surface layer and preventing the penetration of nutrients.

This problem can be softened by the use of baffles that provide larger wetted diameters (Kincaid, 1996; Rodrigues, Pruski, Martinez, \& Silva, 1999). An important variable in the definition of the center pivot radius size is the water infiltration capacity in the soil, variable dependent on the granulometry and soil structure, as well as the terrain slope (Bernardo, Soares, \& Mantovani, 2008). In other words, how much higher the 
infiltration, the higher the rate of water application of the pivot, consequently its area (Cichota, Jong Van Lier, \& Leguizamón Rojas, 2003), his will greatly favor irrigation management, because the equipment may apply larger taxes of irrigation, without risk of surface runoff of water in the soil, at more spaced intervals, wetting the aerial part of the plants fewer times along the cycle, reducing the risk with diseases in its canopy. In areas of high slope and low infiltration soil, there is a real need to reduce the circular area irrigated individually by the pivot to reduce the flow of irrigation water.

Sales et al. (2018) estimate that about $7.1 \%$ of the total cost of production is linked to irrigation. It also points out that $15 \%$ of the total cost of production is linked to the application of pesticides. Thus, it is common to irrigate the tomato crop once a week, to synchronize with the spraying, because with leaf wetting, the plant becomes unprotected (Marouelli, W. Silva, H. Silva, \& Braga, 2012). Studies show that by deepening the root system, with adequate correction, decompaction of the soil, use of rooting, and techniques to increase water retention in the soil, the interval between irrigations can be increased to 10 or 12 days (Bezerra, Alves Júnior, Evangelista, Casaroli, \& Mesquita, 2017), however, the equipment should be prepared for this management, without risk of surface water runoff in the soil.

For farmers who are adopting or intend to adopt this irrigation system (center pivot) and management, information on the physical condition of the soil, especially the infiltration capacity, is fundamental in the project design process. However, when deciding on the size of the pivot (irrigated area), mathematical models need to be created to indicate to the designer the maximum length of the lateral, maximum flows of sprinklers and maximum water application rates at the final end of the pivot, due to the water infiltration capacity of the soils, that is, due to the granulometry (texture) of the soils and different land levels, so that the impact of surface runoff in the soil is previously evaluated by the designer.

In view of these factors, the objective of this study was to simulate the risk of water runoff in the soil for irrigation management in tomato crops, simulating different speeds of displacement of the equipment and different water infiltration capacities in the soil, seeking to find the limit points for each pivot size.

\section{Method}

The simulation study was carried out considering the soil and climatic conditions of Goiânia, GO and the cultivation of tomatoes for industrial processing. The region of the simulation is located in the geographic coordinates $16^{\circ} 35^{\prime}$ of South Latitude and $49^{\circ} 16^{\prime}$ of West Longitude. According to the climate classification of Köppen, the climate of the region is Aw, with annual average temperature, relative humidity $(\mathrm{RH} \%)$ and precipitation of $23{ }^{\circ} \mathrm{C}, 70 \%$ and $1498 \mathrm{~mm}$, respectively (S. Silva, Heinemann, Paz, \& Amorim, 2012). The simulated irrigation system was by a center pivot with four different area sizes, being 25, 50, 75 and 100 hectares, installed in soils with nine different infiltration conditions.

Three types of soils with different physical and water characteristics were used in the simulations (Table 1), combined with three different terrain levels, 0 (at the level), 5 and $10 \%$.

Table 1. Physical-hydro parameters for the different types of soils used in the simulation

\begin{tabular}{llllllllll}
\hline Soil & $\mathrm{Ks}^{*}$ & $\mathrm{PC}^{*}$ & $\mathrm{PWP}^{*}$ & Clay** & Silt** & Sand** & T. Por.* & $\mathrm{U}^{*}$ & $\theta^{*}$ \\
\hline \multirow{3}{*}{ Sandy } & $\mathrm{mm} \mathrm{h}^{-1}$ & $\mathrm{~cm}^{3} \mathrm{~cm}^{-3}$ & & $\%$ & & & & & \\
Medium & 50.00 & 6.00 & 4.00 & 22.10 & 09.70 & 68.20 & 53.00 & 5.00 & 6.00 \\
Clay & 13.00 & 22.00 & 10.00 & 30.55 & 39.35 & 30.10 & 47.00 & 12.00 & 17.00 \\
\hline
\end{tabular}

Note. Ks: Hydraulic conductivity of saturated soil; FC: field capacity; PWP: permanent wilting point; T. Por: total porosity; U: weight based humidity; $\theta$ : volume based humidity; *Valmont (2008); **Mendes et al. (2015).

A fixed level of irrigation of $7.5 \mathrm{~mm}$ was used to project the irrigation system. The management was the same used by Bezerra, Alves Júnior, Evangelista, Casaroli, and Mesquita (2017), where the levels of irrigation varied according to different effective depths of the tomato root system, 25, 30, 35, 40, 45 and $50 \mathrm{~cm}$, in different phases of the crop, resulting in the application of blades of 18.2, 23.0, 27.6, 32.2, 36.8 and $41.4 \mathrm{~mm}$ in phase 3 (flowering at the beginning of ripening) and 21.6, 25.2, 28.8, 32.4, 36.0 and $39.6 \mathrm{~mm}$ in phase 4 (beginning of ripening at harvest). Simulations were performed for these phases, due to the root system of the crop is fully developed, enabling the use of a longer interval between irrigations. 
To calculate the average precipitation intensity $\left(I_{m}\right)$ or the water application rate of the different emitters, the semi-elliptic precipitation distribution model was used, which can express the precipitation intensity, as a function of the total flow of the system, by Equation 1 (Bittinger \& Longenbaugh, 1962).

$$
I_{m}=\frac{3 q}{2 \pi d_{s p}}
$$

where, $I_{m}$ is the average precipitation intensity $\left(\mathrm{mm} \mathrm{h}^{-1}\right), q$ is the flow rate of the sprinkler in the analyzed section $\left(\mathrm{L} \mathrm{h}^{-1}\right)$ and $d_{s p}$ being the wetted diameter of the sprinkler $(\mathrm{m})$.

For comparison purposes, Ip was simulated to two types of deflectors with different wetted diameters, both from Senninger ${ }^{\circledR}$, one from Super-Spray ${ }^{\circledR}$ and another from I-Wob UP $2 \AA$, with average wet diameters of 8.2 and $14.8 \mathrm{~m}$.

After the design of the sides of center pivots with their respective emitter nozzle sequences, the energy produced by the drop was calculated (Equation 2). Kincaid (1996), monitoring the physical effects caused by the droplet produced by the application of water to the soil with different types of emitters, determined an empirical equation for the estimation of the average diameter of the droplets produced as a function of the nozzle diameter and its service pressure (Equation 3).

$$
\begin{gathered}
E_{k}=e_{0}+e_{1} \frac{D_{n}}{H} \\
d_{50}=\frac{E_{k}+2.79}{7.2}
\end{gathered}
$$

where, $E_{k}$ is the kinetic energy produced by the droplet $\left(\mathrm{J} \mathrm{kg}^{-1}\right), e_{0}$ and $e_{1}$ are variable coefficients depending on the type of emitter, $D_{n}$ is the nozzle diameter $(\mathrm{mm}), H$ is the emitter service pressure $(\mathrm{m})$ and $d_{50}$ is the average diameter of the droplets produced.

The water infiltration rate reduction factor resulting from soil surface sealing was calculated by means of the model proposed by (Bernuth \& Gilley, 1985) (Equation 4).

$$
F_{r}=3.541 d_{50}^{0.683} v_{\mathrm{d}}^{1.271} p_{s a}{ }^{-0.353} p_{s}^{0.257}
$$

where, $F_{r}$ is the factor for reducing the hydraulic conductivity of saturated soil $(\%), v_{d}$ is the droplet velocity (m $\left.\mathrm{s}^{-1}\right), p_{s a}$ is the sand percentage (\%) and $p_{s}$ the silt percentage (\%).

The maximum velocity with which the drop reaches the soil surface as a function of its diameter was calculated by the model adjusted by Rodrigues, Pruski, and E. Silva, (2003) in function of these variables and obtained by Keller and Bliesner (1990) (Equation 5).

$$
v_{d}=-0.6133+2.3844 d_{50}-1.0772 d_{50}^{2}+0.0779 d_{50}{ }^{3}
$$

The models proposed in Equations 2, 3, 4 and 5 allow calculating the reduction of the dynamic hydraulic conductivity as a function of the factor of reduction of the infiltration of water in the soil, caused by the energy produced by the drop of the emitter applied to the soil.

Surface storage was calculated by the proposed method by Osntad (1984), is this, variable according to the physical properties of the soil surface, being the roughness of the soil surface a dynamic property that interferes in the process of storage and surface runoff (Equation 6).

$$
S_{s}=0.112 R R+3.1 R R^{2}+1.2 R R J
$$

where, $S_{s}$ is the surface storage in (m), $R R$ the random roughness (m) and $J$ the slope of the soil surface.

The maximum allowable precipitation intensity $\left(I_{p m a}\right)$ was calculated by the model proposed by Rodrigues, Pruski, Martinez and E. Silva (1999), which takes into account the critical moment when the representative precipitation intensity curve touches the infiltration capacity curve, generating a value, in $\mathrm{mm} \mathrm{h}^{-1}$, of the maximum allowable intensity for a given soil, climate and crop condition (Equation 7).

$$
I_{p m a}=\frac{4.47 K_{h}\left(S_{s}-L(t)-S_{w} \theta_{d}\right) L_{p}}{\left[A_{s}-L(t)\right]\left[L_{p}(\xi)-78.96 L^{2}(t)\right]}
$$

where, $K_{h}$ is the hydraulic conductivity of saturated soil as a function of the reduction factor of water infiltration reduction in the soil (mm), $S_{s}$ is the maximum surface storage $(\mathrm{m}), L(t)$ is the level of irrigation applied to the soil as a function of time $(\mathrm{mm}), S_{w}$ is the average matrix potential in front of wetting $(\mathrm{mm}), \theta_{d}$ being the available humidity $\left(\mathrm{cm}^{3} \mathrm{~cm}^{-3}\right)$ and $L p$ the total level of irrigation to be applied $(\mathrm{mm})$.

The equations are solved by Newton-Raphson's numerical technique. The procedure consists of assigning an initial value for $\mathrm{L}(\mathrm{t})$ in Equation 7 and calculating the value of the maximum allowable precipitation intensity. The values of $\mathrm{L}(\mathrm{t})$ and Ipma are then replaced in Equations 8 and 9, and the error is calculated by Equation 10 . 
The procedure ends when the error module (Equation 11) is lower than the desired precision. In this study, the accuracy of 0.0001 was adopted.

\section{Results}

$$
\begin{gathered}
\Omega=\frac{44.13 I_{p m a}\left[L_{p}-2 L(t)\right]}{\left.5\left[L_{p} \xi-78.96 L^{2}(t)\right]\right]^{0.5} L_{p}}+\frac{K_{h} S_{w} \theta_{d}}{\left[S_{s}-L(t)\right]^{2}} \\
\frac{d(\Omega)}{d(L(t))}=\frac{2 K_{h} S_{w} \theta_{d}}{\left[S_{s}-L(t)\right]^{3}}-\frac{1853.80 I \text { pma } L_{p}}{\left\{L_{p}\left[\xi-78.96 L^{2}(t)\right]^{1.5}\right\}} \\
\xi=78.96 L(t)+1.26 L_{p} \\
\text { Erro }=\frac{\Omega}{d(\Omega) / d(L(t))}
\end{gathered}
$$

The variations in the maximum allowable precipitation intensity (ipma) and in the application intensity of the emitters for the different irrigated areas, slope levels, and soil texture can be seen in Figures 1, 2, 3 and 4.
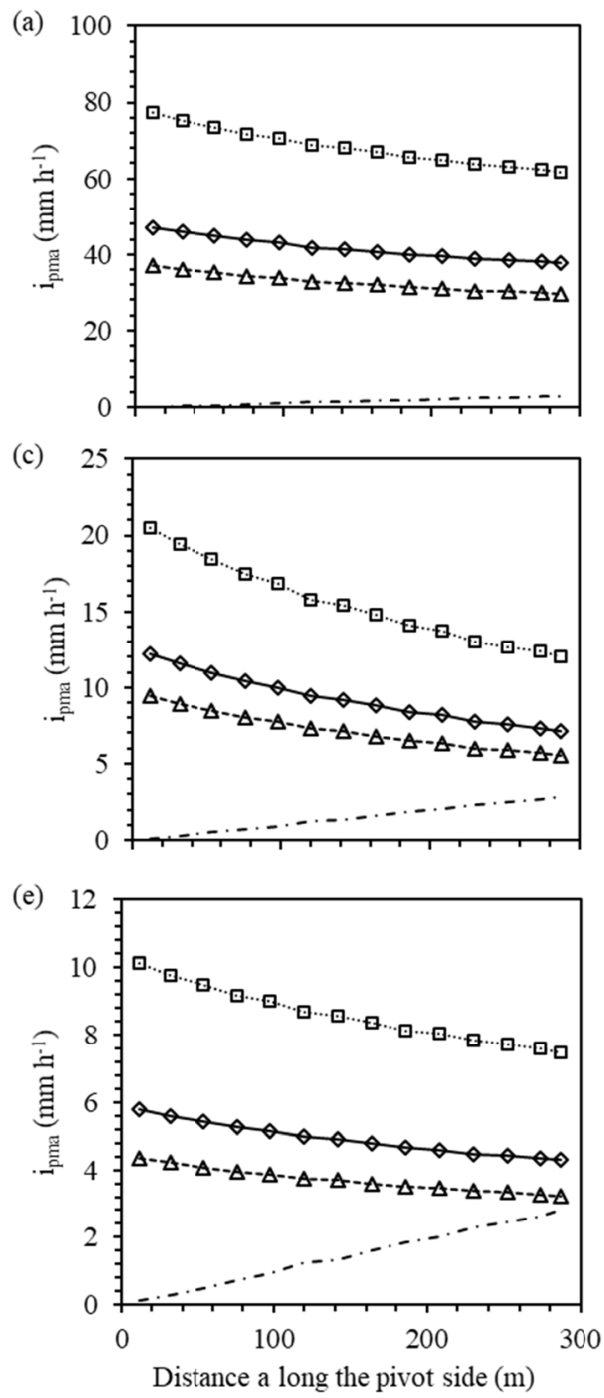

(b)

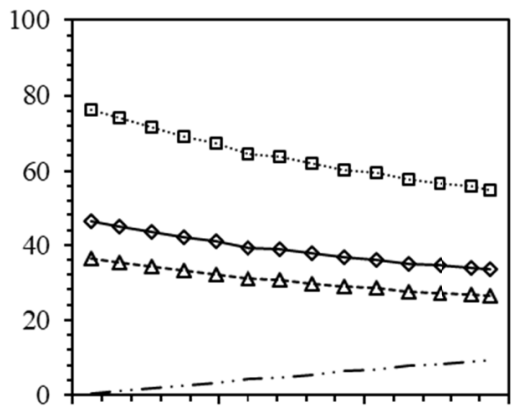

(d)

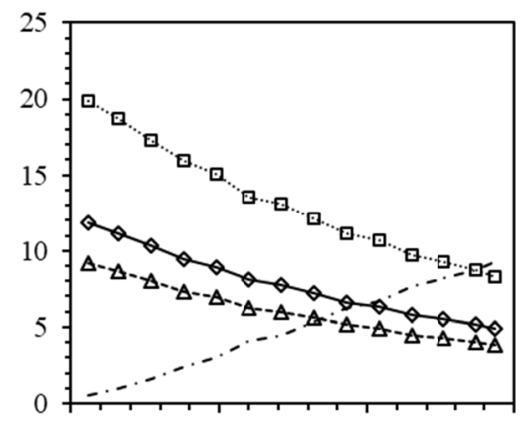

(f)

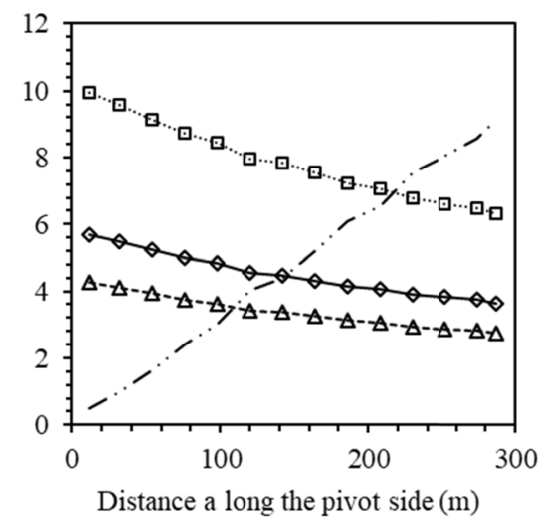

Figure 1. Maximum allowable precipitation intensity values $\left(\mathrm{I}_{\mathrm{pma}}\right)$ and application intensity of the Senninger I-Wob and Low Pressure Sprinklers Spray, for a pivot of 25 hectares, at different inclination levels, 0, 5 and $10 \%$, Sandy soil with I-Wob (a); Sandy soil with Spray (b); Medium soil with I-Wob (c); Medium soil with Spray (d); Clay soil with I-Wob (e); Clay soil with Spray (f) 

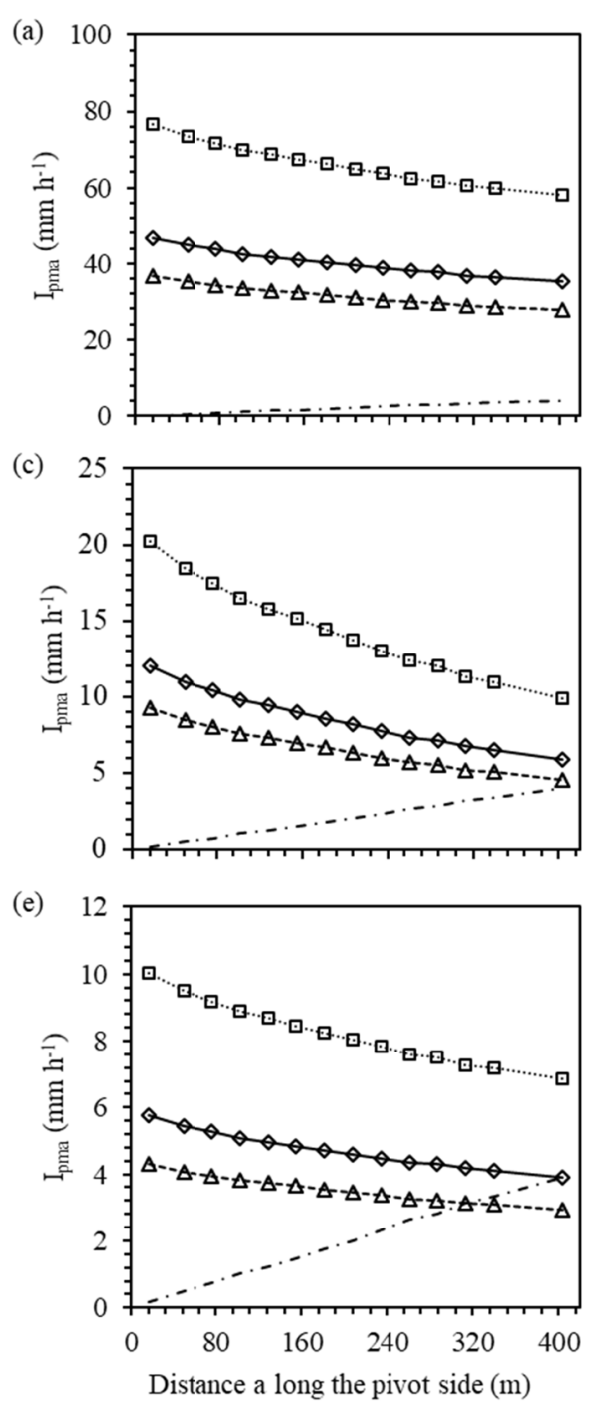

(b)

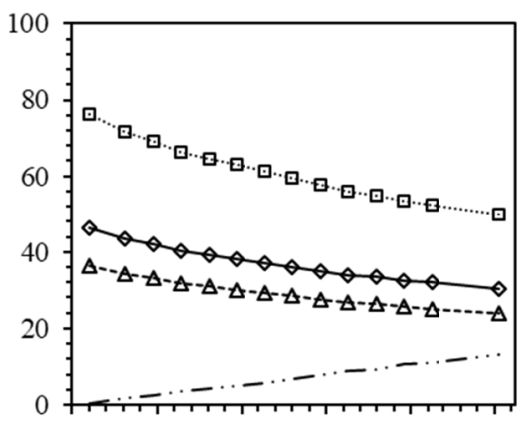

(d)

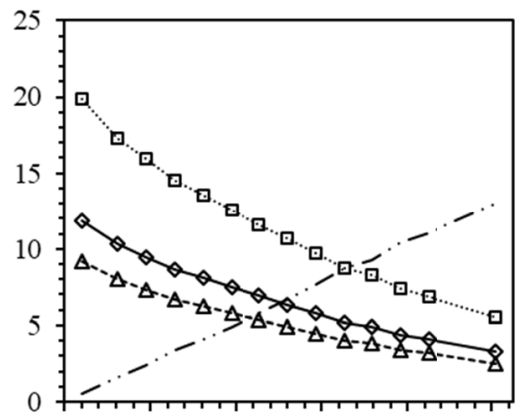

(f)

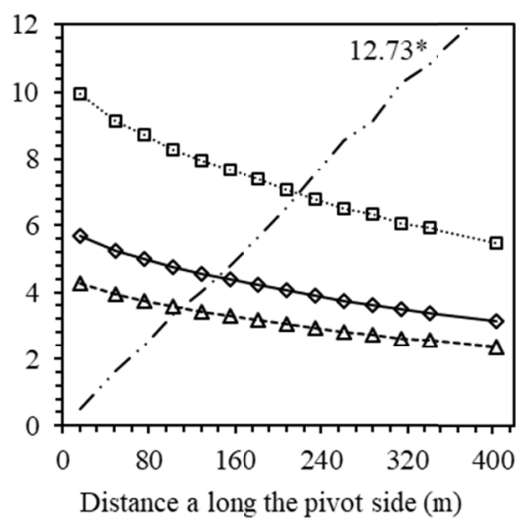

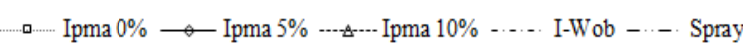

Figure 2. Values of maximum allowable precipitation intensity $\left(\mathrm{I}_{\mathrm{pma}}\right)$ and application intensity of Senninger I-Wob and Low Pressure Sprinkler Spray, for a 50 hectare pivot, at different inclination levels, 0, 5 and 10\%, Sandy soil with I-Wob (a); Sandy soil with Spray (b); Medium soil with I-Wob (c); Medium soil with Spray (d); Clay soil with I-Wob (e); Clay soil with Spray (f). * Maximum values of application intensity 

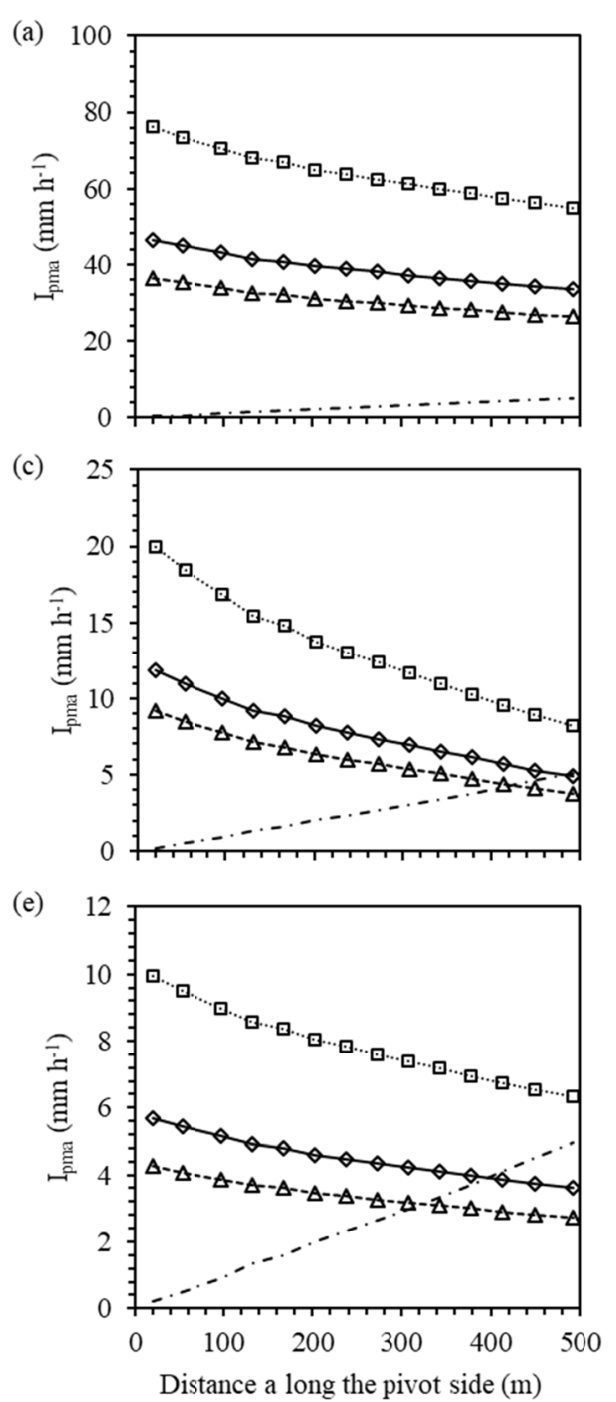

(b) 100

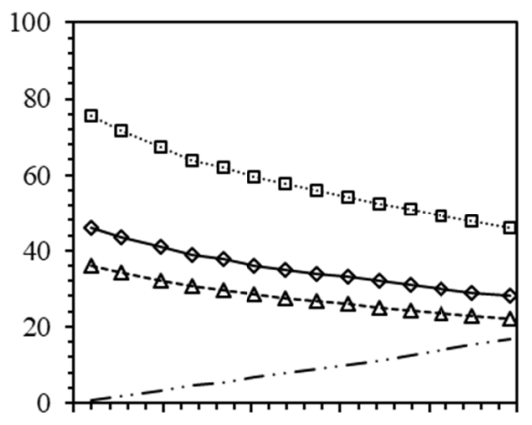

(d)

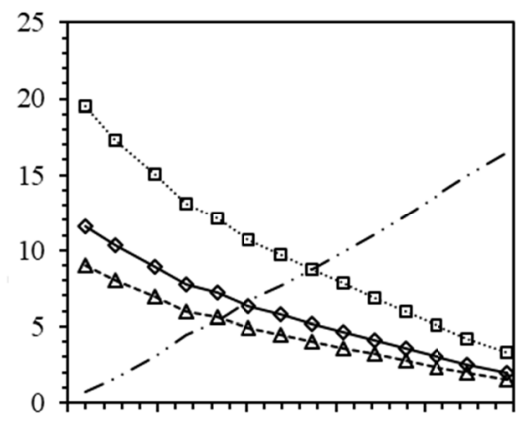

(f)

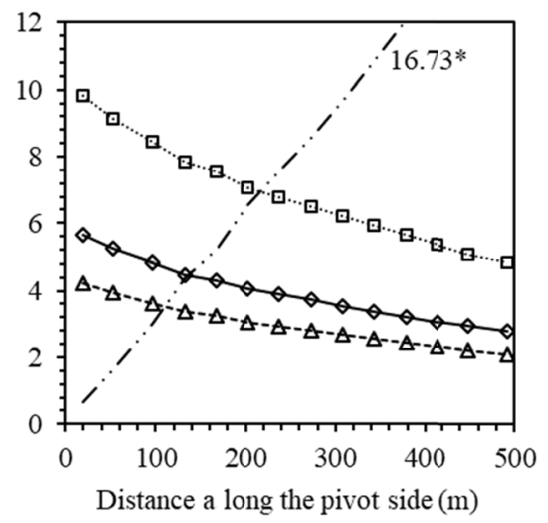

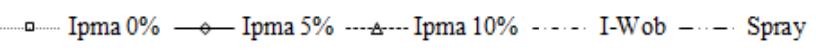

Figure 3. Values of maximum allowable precipitation intensity $\left(\mathrm{I}_{\mathrm{pma}}\right)$ and application intensity of Senninger I-Wob and Low Pressure Sprinkler Spray, for a 75 hectare pivot, at different inclination levels, 0, 5 and 10\%, Sandy soil with I-Wob (a); Sandy soil with Spray (b); Medium soil with I-Wob (c); Medium soil with Spray (d); Clay soil with I-Wob (e); Clay soil with Spray (f). * Maximum values of application intensity 

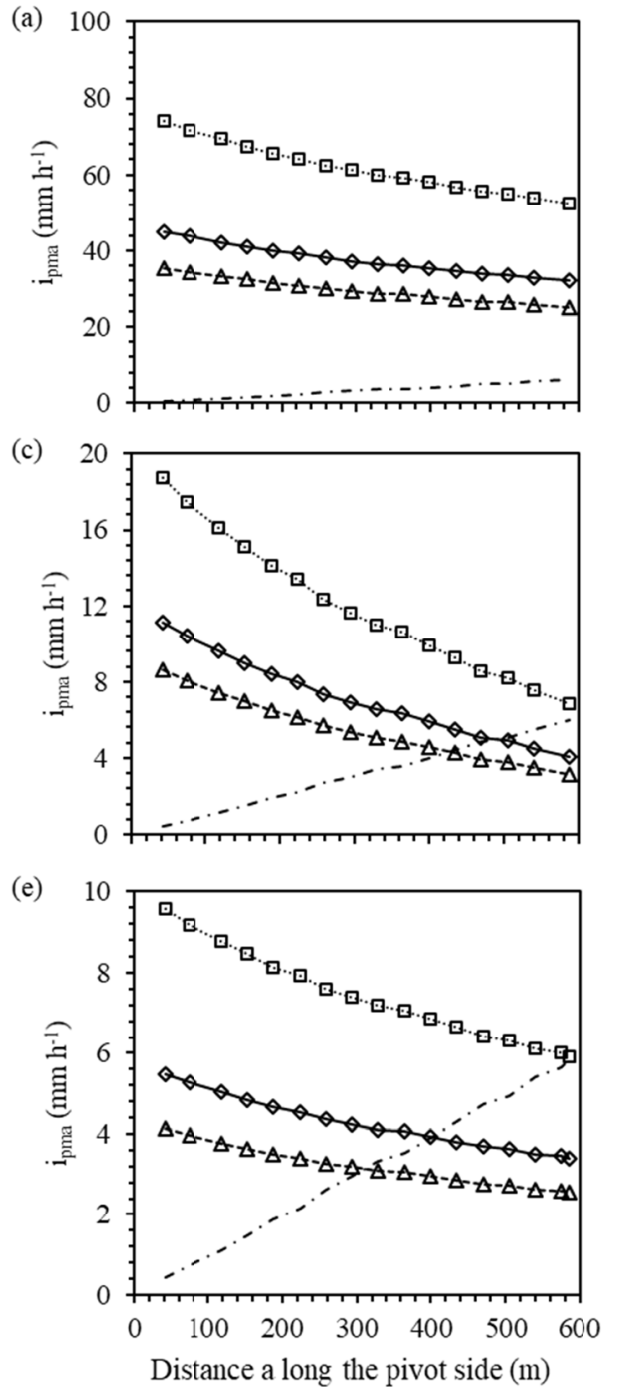

(b)

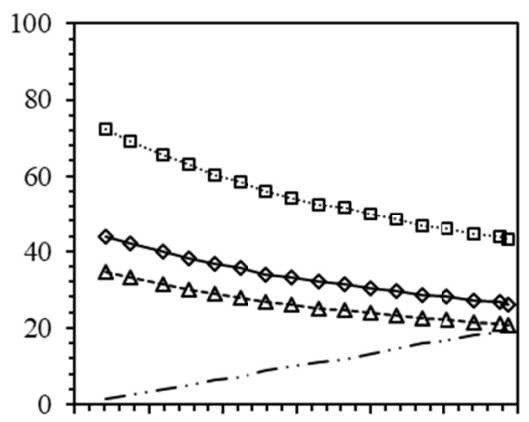

(d)

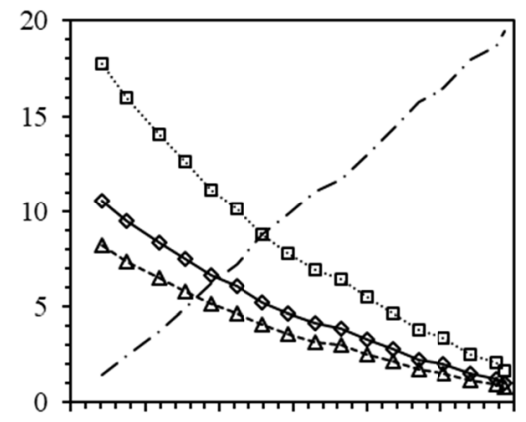

(f)

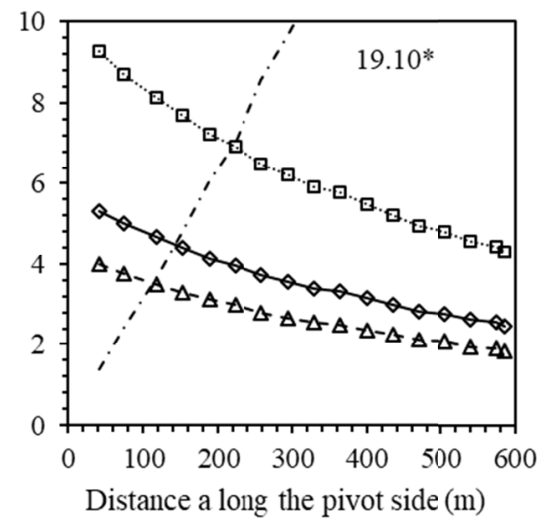

Figure 4. Values of maximum allowable precipitation intensity $\left(\mathrm{I}_{\mathrm{pma}}\right)$ and application intensity of Senninger I-Wob and Low Pressure Sprinkler Spray, for a 100 hectare pivot, at different inclination levels, 0, 5 and 10\%, Sandy soil with I-Wob (a); Sandy soil with Spray (b); Medium soil with I-Wob (c); Medium soil with Spray (d); Clay soil with I-Wob (e); Clay soil with Spray (f). * Maximum values of application intensity

As the side length of the center pivot increases, the value of the maximum allowable water application intensity of the center pivot is reduced. This indicates that for the same ground conditions and levels of irrigation to be applied, then bigger the side length, the greater the risk of surface runoff occurs. This is because in the center pivot type irrigation system, as the area to be irrigated by an emitter moves away from its center, it increases, requiring that its water application intensity is higher, to ensure uniformity of application.

Comparing a flat ground terrain with those with a slope of $5 \%$, the reduction in the maximum allowable precipitaion intensity values is $40.74 \%$, from 5 to $10 \%$ slope the reduction is $22.99 \%$. This can be explained by the decrease in surface storage values as the slope of the land increases. Winkler et al. (2018) verified the same behavior working with different slopes. The higher the slope, the lower the surface storage capacity.

Another determining factor is the random roughness, which is a dynamic property of the soil that directly interferes in the processes of infiltration and storage of water in the soil. The roughness of the soil surface has an influence due to the management and initial preparation of the soil, with appropriate techniques, the soil presents greater stability between its aggregates, greater aeration and better infiltration capacity (Silva et al., 2015). 
The variation in the $\mathrm{I}_{\text {pma }}$ with respect to the texture of the three types of soils evaluated occurred because the intensity of water redistribution in the soil was entirely related to its texture (Perrens, 1984). The physical-hydro attribute of the soil that relates its texture to the water infiltration capacity is the hydraulic conductivity (Bouwer, 1986). Soils with higher hydraulic conductivity present higher infiltration rates. Bernardo, Soares and Mantovani (2008) classify the infiltration rates of sandy soils as the highest $\left(>30 \mathrm{~mm} \mathrm{~h}^{-1}\right)$, followed by those of medium texture $\left(10\right.$ to $\left.20 \mathrm{~mm} \mathrm{~h}^{-1}\right)$ and clayey $\left(<5 \mathrm{~mm} \mathrm{~h}^{-1}\right)$, making them more susceptible to runoff from clayey soils, same effect observed in the study. Classifying the types of soils according to their $\mathrm{I}_{\text {pma }}$ we have: sand $>$ medium $>$ clayey.

The type of deflector also influences the surface runoff process. Deflectors that have a greater radius of reach have an advantage in terms of the distribution of the volume of water applied. There is a greater intensity of application in deflectors Spray. This higher intensity of application is related to a smaller reach area. Therefore, higher levels of surface runoff and soil particle detachment are produced by grooved baffles, which also lead to higher sediment production and even soil erosion (Silva, 2006). Thus, I-Wob type deflector present a better distribution of the volume of water applied, due to their greater radius of reach, which may decrease the incidence of surface runoff.

The intensities of application of the last sprinkler on the side of the pivot for the different irrigated areas, type of emitter and soil texture, can be seen in Table 2. Table 3 shows the maximum application intensities suggested per emitter for each soil type.

Table 2. Intensity of application $\left(\mathrm{mm} \mathrm{h}^{-1}\right)$ of the last emitter in center pivots of four different sizes $(25,50,75$ and $100 \mathrm{ha}$ ), with two types of deflectors (I-Wob and Spray), installed in soils of different textures (sandy, medium and clayey)

\begin{tabular}{|c|c|c|c|c|}
\hline \multirow{3}{*}{ Pivot area (ha) } & \multirow{3}{*}{ Deflector } & \multicolumn{3}{|c|}{ Texture } \\
\hline & & Sandy & Medium & Clayey \\
\hline & & \multicolumn{3}{|c|}{ Maximum application intensity $\left(\mathrm{mm} \mathrm{h}^{-1}\right)$} \\
\hline \multirow{2}{*}{25} & I-Wob & 2.89 & 2.86 & 2.80 \\
\hline & Spray & 9.41 & 9.30 & 9.12 \\
\hline \multirow{2}{*}{50} & $\mathrm{I}-\mathrm{Wob}$ & 4.03 & 3.89 & 3.91 \\
\hline & Spray & 13.13 & 12.98 & 12.73 \\
\hline \multirow{2}{*}{75} & I-Wob & 5.11 & 5.05 & 4.95 \\
\hline & Spray & 16.64 & 16.45 & 16.13 \\
\hline \multirow{2}{*}{100} & I-Wob & 6.05 & 5.98 & 5.86 \\
\hline & Spray & 19.70 & 19.47 & 19.10 \\
\hline
\end{tabular}

Note. Organized by the authors.

Table 3. Maximum suggested application intensity $\left(\mathrm{mm} \mathrm{h}^{-1}\right)$ as a function of soil type and declivity

\begin{tabular}{lccc}
\hline \multirow{2}{*}{ Texture } & \multicolumn{3}{c}{ Declivity (\%) } \\
\cline { 2 - 4 } & 0 & \multicolumn{3}{c}{5} & 10 \\
\cline { 2 - 4 } & 25 & 20 & Maximum application intensity $\left(\mathrm{mm} \mathrm{h}^{-1}\right)$ \\
\hline Sandy & 13 & 10 & 12.5 \\
Medium & 4 & 2.5 & 6 \\
Clayvey & & & 2 \\
\hline
\end{tabular}

Note. Adapted from Keller and Bliesner (1990).

$I_{p m a}$ values and suggested maximum application intensity values indicate that in center pivots of both sizes studied there is the possibility of surface runoff. Spray deflectors have lower application intensity than suggested by Keller and Bliesner (1990) only in pivots of 25 ha installed in sandy soils and in flat terrains. Clayey soils are extremely susceptible to surface runoff and in this study only the 25 ha pivot with $0 \%$ slope showed acceptable application intensity.

The classifications and indications of pivots sizes regarding the soil type are presented in Table 4 . 
Table 4. Recommendation for the installation of center pivots, relating soil type and slope

\begin{tabular}{|c|c|c|c|c|c|c|c|c|c|c|}
\hline \multirow{3}{*}{ Pivot area (ha) } & \multirow{3}{*}{ Deflector } & \multicolumn{9}{|c|}{ Declivity (\%) } \\
\hline & & \multicolumn{3}{|c|}{ Sandy } & \multicolumn{3}{|c|}{ Medium } & \multicolumn{3}{|c|}{ Clayey } \\
\hline & & 0 & 5 & 10 & 0 & 5 & 10 & 0 & 5 & 10 \\
\hline \multirow{2}{*}{25} & I-Wob & $\mathrm{X}$ & $\mathrm{X}$ & $\mathrm{X}$ & $\mathrm{X}$ & $\mathrm{X}$ & $\mathrm{X}$ & $\mathrm{X}$ & & \\
\hline & Spray & $\mathrm{X}$ & $\mathrm{X}$ & $\mathrm{X}$ & $\mathrm{X}$ & $\mathrm{X}$ & & & & \\
\hline \multirow{2}{*}{50} & I-Wob & $X$ & $\mathrm{X}$ & $X$ & $\mathrm{X}$ & $\mathrm{X}$ & $X$ & $\mathrm{X}$ & & \\
\hline & Spray & $\mathrm{X}$ & $\mathrm{X}$ & $\mathrm{X}$ & $\mathrm{X}$ & & & & & \\
\hline \multirow{2}{*}{75} & $\mathrm{I}-\mathrm{Wob}$ & $X$ & $X$ & $X$ & $X$ & $\bar{X}$ & $X$ & & & \\
\hline & Spray & $\mathrm{X}$ & $\mathrm{X}$ & & & & & & & \\
\hline \multirow{2}{*}{100} & $\mathrm{I}-\mathrm{Wob}$ & $\mathrm{X}$ & $x$ & $\mathrm{X}$ & $X$ & $\mathrm{X}$ & $X^{-}$ & & & \\
\hline & Spray & $\mathrm{X}$ & $\mathrm{X}$ & & & & & & & \\
\hline
\end{tabular}

Note. Organized by the authors.

Figure 5 shows the values of $I_{\text {pma }}$ as a function of the different levels of irrigation adopted in irrigation management in different phases of tomato for processing development.
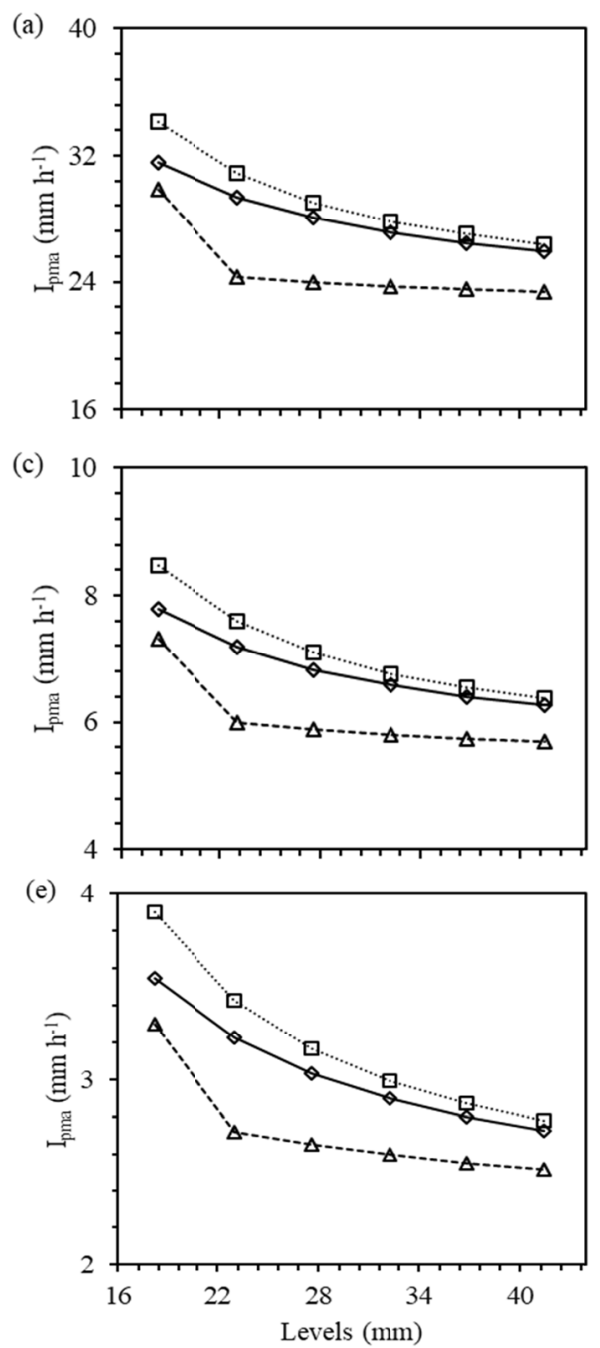

(b)

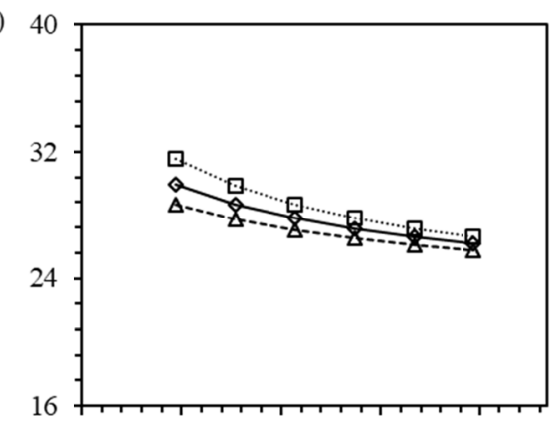

(d)

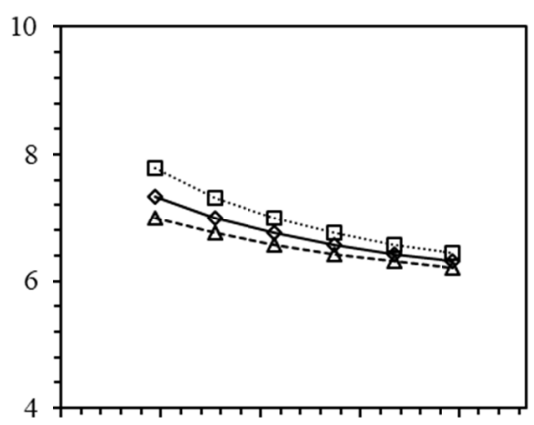

(f)

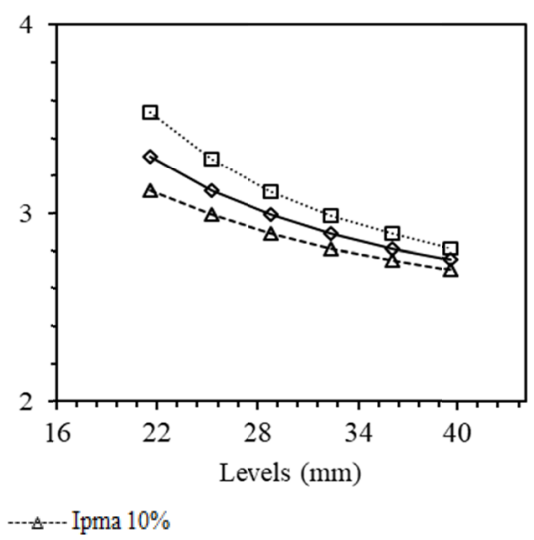

Figure 5. Values of the maximum allowable precipitation intensity $\left(\mathrm{I}_{\mathrm{pma}}\right)$ for a center pivot, at different inclination levels, 0,5 and $10 \%$, at different levels of irrigation 18.2, 23.0, 27.6, 32.2, 36.8 and $41.4 \mathrm{~mm}$ in phase 3 and 21.6, 25.2, 28.8, 32.4, 36.0 and $39.6 \mathrm{~mm}$ in phase 4. Sandy soil phase 3 (a); Sandy soil phase 4 (b);

Medium soil phase 3 (c); Medium soil phase 4 (d); Clay soil with phase 3 (e); Clay soil phase 4 (f) 
The value of $\mathrm{I}_{\mathrm{pma}}$ is more accentuated in smaller irrigations levels. The irrigations levels passed from 18.2, 23.0, 27.6, 32.2, 36.8 and $41.4 \mathrm{~mm}$ in phase 3 of tomato development and 21.6, 25.2, 28.8, 32.4, 36.0 and $39.6 \mathrm{~mm}$ in phase 4 , with, a decrease in the value of $\mathrm{I}_{\text {pma }}$, showing that the longer interval between irrigations increases the risk of surface runoff. It is also possible to observe that smaller levels of irrigation present greater variation of $\mathrm{I}_{\mathrm{pma}}$. For example, in Figure 5c it is possible to observe that in the 18.2 and $23.0 \mathrm{~mm}$ slides, the values of $\mathrm{I}_{\mathrm{pma}}$ increased from 8.47 to 7.58 , varying from $0.89 \mathrm{~mm} \mathrm{~h}^{-1}$. On the other hand, when the slide went from 36.8 to 41.4 $\mathrm{mm}$, the ipma went from 6.54 to $6.37 \mathrm{~mm} \mathrm{~h}^{-1}$, thus there was a variation in the $\mathrm{I}_{\mathrm{pma}}$ value of $0.17 \mathrm{~mm} \mathrm{~h}^{-1}$. This result allows us to conclude that the risk of occurrence of surface runoff is higher in systems designed to apply large irrigation levels. pivots with small irrigations levels require greater attention regarding the operation, since operator interference in these systems may be a risk since the $I_{p m a}$ variation is greater.

A solution for linearization of the $\mathrm{I}_{\mathrm{pma}}$ curve and better use of the infiltration capacity along the side of the pivot would be the variation of the service pressure of the emitter. Higher pressures applied to a nozzle of the same diameter cause a greater fragmentation of the droplet, consequently, these drops have lower speed and average diameter, making the $\mathrm{I}_{\text {pma }}$ greater (Figure 6). Silva (2006) observed the same behavior, larger droplets have greater impact energy on the soil surface, increasing sealing and crusts on the soil surface, which reduce infiltration and increase runoff.
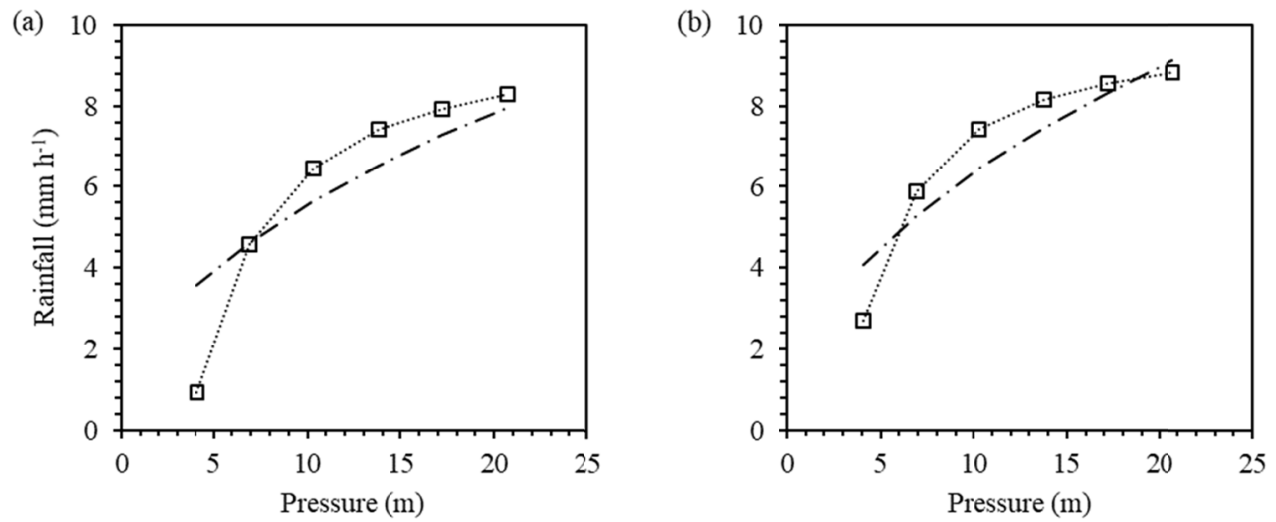

Figure 6. Precipitation intensity values (Ip) and maximum allowable (Ipma) as a function of the working pressure of the sprinkler, I-Wob (a) and Spray (b)

\section{Conclusions}

Based on the simulated models, clayey soils are the most susceptible to surface runoff.

The risk of surface runoff is higher in systems sized for areas larger than 50 hectares and systems with high irrigation levels.

Among the deflectors used, the I-Wob stands out with lower precipitation intensity and better water distribution for infiltration.

\section{References}

Bernardo, S., Soares, A. A., \& Mantovani, E. C. (2008). Manual de Irrigação (6th ed.). Viçosa: UFV.

Bernuth, R. D., \& Gilley, J. R. (1985). Evaluation of center pivot application packages considering droplet induced infiltration reduction. Transactions of the ASAE, 28(6), 1940-1946. https://doi.org/10.13031/2013. 32545

Bezerra, R. S., Alves Júnior, J., Evangelista, A. W. P., Casaroli, D., \& Mesquita, M. (2017). Influência da frequência de irrigação no custo de produção do tomateiro industrial irrigado por aspersão. Agro Tecnologia, 8(1), 10-17. https://doi.org/10.12971/agrotec.v8i1.5551

Bittinger, M. W., \& Longenbaugh, R. A. (1962). Theoretical distribution of water from a moving irrigation sprinkler. Transactions of the ASAE, 5(1), 26-30. https://doi.org/10.13031/10.13031/2013.40926 
Bouwer, H. (1986). In take rate: cylinder infiltrometer. In A. Klute (Ed.), Methods of Soil Analysis: Part 1-Physical and Mineralogical Methods (2nd ed., pp. 825-844). Madison: American Society of Agronomy; Soil Science Society of America.

Cichota, R., Jong Van Lier, Q. de, \& Leguizamón Rojas, C. A. (2003). Variabilidade espacial da taxa de infiltração em Argissolo Vermelho. Revista Brasileira de Ciência do Solo, 27(5), 789-798. https://doi.org/ 10.1590/S0100-06832003000500003

FAEG (Federação da Agricultura e Pecuária de Goiás). (2014). Index: Notícias. Retrieved from http://sistemafaeg.com.br/noticias?start=30

Keller, J., \& Bliesner, R. D. (1990). Sprinkler and trickle irrigation. New York: Van Nostrand Reinhold. https://doi.org/10.1007/978-1-4757-1425-8

Kincaid, D. C. (1996). Spraydrop kinetic energy from irrigation sprinklers. Transactions of the ASAE, 39(3), 847-853. https://dx.doi.org/10.13031/2013.27569

Kincaid, D. C. (2005). Application rates from center pivot irrigation with current sprinkler types. Applied Engineering in Agriculture, 21(4), 605-610. https://doi.org/10.13031/2013.27569

Maciel Netto, A., Antonino, A. C. D., Audry, P., Carneiro, C. J. G., \& Olio, A. D. (2000). Condutividade hidráulica não saturada de um podzólico amarelo da zona da mata norte de Pernambuco. Pesquisa Agropecuária Brasileira, 35(6), 1221-1228. https://doi.org/10.1590/S0100-204X2000000600019

Marouelli, W. A., Silva, W. L. C., Silva, H. R., \& Braga, M. B. (2012). Irrigação e fertirrigação. In F. M. V. T. Clemente, \& L. S. Boiteux (Eds.), Produção de tomate para processamento industrial (pp. 15-27). Brasília: Embrapa.

Mendes, W. D. C., Alves Júnior, J., Cunha, P. C. R. D., Silva, A. R. D., Evangelista, A. W. P., \& Casaroli, D. (2015). Lixiviação de nitrato em função de lâminas de irrigação em um solo argiloso e solo arenoso. Irriga \& Inovagri, 1(2), 47-56. https://doi.org/10.15809/irriga.2015v1n2p47

Onstad, C. A. (1984). Depressional storage on tilled soil surfaces. Transactions of the ASAE, 27(3), 729-732. https://doi.org/10.13031/2013.32861

Perrens, S. J. (1984) Numerical analysis of soil water uniformity under sprinkler irrigation. Journal Agricultural Engineering Research, 30, 23-27. https://doi.org/10.1016/S0021-8634(84)80002-5

Rodrigues, L. N., Pruski, F. F., \& Da Silva, E. M. (2003). Procedimento para estimativa da intensidade de precipitação máxima admissível em pivô-central com base nas características do equipamento e do solo. Planaltina: Embrapa Cerrados-Documentos (INFOTECA-E).

Rodrigues, L. N., Pruski, F. F., Martinez, M. A. D. D., \& Silva, E. M. (1999) Metodologia para estimativa da intensidade de precipitação máxima admissível em pivô-central. Engenharia Agrícola, 19(2), 151-162.

Sales, D. L. A., Alves Júnior, J., Pereira, R. M., Rodriguez, W. D. M., Casaroli, D., \& Evangelista, A. W. P. (2017) Viabilidade ecônomica da irrigação por pivô central nas culturas de soja, milho e tomate. Pesquisa Agropecuária Pernambucana, 22, 1-6. https://doi.org/10.12661/pap.2017.011

Silva, E. M., \& Azevedo, J. A. (1998) Dimensionamento da lateral de irrigação do pivô-central. Planaltina: Embrapa Cerrados-Documentos (INFOTECA-E).

Silva, H. D., Favaretto, N., Cavalieri, K. M. V., Dieckow, J., Vezzani, F. M., Parron, L. M., ... Ferrari Neto, H. (2015). Atributos físicos do solo e escoamento superficial como indicadores de serviços ambientais. Embrapa Florestas-Capítulo em livro científico (ALICE).

Silva, L. L. (2006). The effect of spray head sprinklers with different deflector plates on irrigation uniformity, runoff and sediment yield in a Mediterranean soil. Agricultural Water Management, 85(3), $243-252$. https://doi.org/10.1016/j.agwat.2006.05.006

Silva, S. C. da, Heinemann, A. B., Paz, R. L. F., \& Amorim, A. de O. (2014). Informações Meteorológicas para Pesquisa e Planejamento Agrícola, Referentes ao Município de Santo Antônio de Goiás, GO, 2012. Santo Antônio de Goiás: Embrapa Arroz e Feijão.

Valmont. (2008). Manual de Projetos: Dimensionamento passo-a-passo pivot central Valley (1st ed.). Uberaba: Valmont. 
Winkler, A. S., Silva, J. T. D., Parfitt, J., Teixeira-Gandra, C. F., Conceço, G., \& Timm, L. C. (2018). Surface drainage in leveled land: Implication of slope. Revista Brasileira de Engenharia Agrícola e Ambiental, 22(2), 77-82. https://doi.org/10.1590/1807-1929/agriambi.v22n2p77-82

\section{Copyrights}

Copyright for this article is retained by the author(s), with first publication rights granted to the journal.

This is an open-access article distributed under the terms and conditions of the Creative Commons Attribution license (http://creativecommons.org/licenses/by/4.0/). 